\title{
MEMAKSIMALKAN LEMBAGA PENJAMIN KREDIT DALAM MEMPERMUDAHMENDAPATKAN KREDIT
}

\author{
Mia Lasmi Wardiyah \\ Dosen Fakultas Syariah dan Hukum \\ Universitas Islam Negeri Sunan Gunung Djati Bandung
}

\begin{abstract}
Abstrak
Makalah ini membahas mengenai UMKM dan permasalahanpermasalahan yang dihadapinya, terutama dalam usaha mendapatkan sumber dana. Persoalan klasik, yang selalu didapat dari para UMKM ini,dalam mendapatkan sumber dana, adalah keharusan memiliki agunan, banyaknya biaya yang harus dikeluarkan, yang nilainya cukup besar, dalam setiap pengurusan kredit.Program Menkeu pada dasarnya memihak pada para UMKM dalam usaha mendapatkan sumber dana secara mudah, melalui program penguatan kapasitas Lembaga Penjamin Kredit UMKM. Sehingga dengan kuatnya Lembaga Penjamin Kredit ini maka akan meningkatkan kemampuan UMKM, yang tidak atau kurang memiliki agunan, dengan membagi resiko antara Bank dengan Lembaga Penjamin Kredit. Dengan demikian akan meningkatkan kemauan Perbankan dalam menyalurkan kredit pada UMKM. Lembaga Penjamin Kredit dapat dianggap sebagai jembatan antara para pengusaha kecil,yang tidak mempunyai agunan, dengan pihak Bank.Undang-Undang No. 9 Tahun 1995, menjelaskan mengenai apa itu UMKM, usaha-usaha apa saja yang dilakukan oleh Pemerintah dalam memajukan para pengusaha UMKM ini, serta berbagai sanksi hukum yang diambil Pemerintah terhadap para kreditur dan debitur yang nakal.
\end{abstract}

Kata Kunci:

Usaha Mikro, Kredit, Lembaga, UMKM

\section{A. Pendahuluan}

Salah satu masalah pengembangan Usaha Menengah Kecil dan Mikro (UMKM) di Indonesia adalah rendahnya akses terhadap sum- 
144 | Adliya, Vol. 8 No. 1, Edisi: Januari-Juni 2014

ber permodalan. Penyebabnya antara lain karena terbatasnya jaminan atau agunan yang umumnya selalu disyaratkan oleh Bank (Bank Teknis). Untuk itu perlu kehadiran lembaga yang berfungsi untuk melakukan penjaminan atas transaksi yang dilakukan UMKM dengan pihak ketiga (Bank/Lembaga Keuangan lainnya).

Persoalan UMKM yang paling sering ditemukan di lapangan, antara lain adalah:

1. Keterbatasan modal;

2. Kurangnya akses UMKM ke Perbankan;

3. Keterbatasan Lembaga Keuangan Non-Bank untuk memperoleh kredit usaha;

4. Keterbatasan kualitas produk-produk yang dihasilkan oleh para UMKM tersebut;

5. Keterbatasan para UMKM dalam kemampuan memasarkan produk yang dihasilkannya.

Kendala mengakses permodalan, terhadap Perbankan, disebabkan prinsip kehati-hatian, sehingga menerapkan prosedur dan persyaratan kredit relatif rumit dan birokratis. Ketidakmampuan dalam menyediakan jaminan tambahan, kelengkapan legalitas usaha, terbatasnya jangkauan pelayanan kredit, tingginya bunga kredit, dan terbatasnya fasilitas kredit layak usaha dari perbankan, dijadikan alasan perbankan untuk tidak memberikan kredit kepada UMKM. Fenomena ini terjadi karena adanya masalah krusial dalam sektor keuangan yaitu terjadinya asimertri/ketidaksamaan informasi ${ }^{1}$. Yakni suatu situasi dimana satu pihak yang terlibat dalam kesepakatan keuangan memiliki informasi yang akurat dibanding pihak lain. Adapun masalah asimetri ini mencakup dua hal, yaitu;

(i) “Adverse Selection”, suatu bentukmasalah asimetri informasi yang terjadi sebelum transaksi keuangan dilakukan, karena peminjam dengan kualitas rendah (memiliki resiko kredit tinggi) biasanya mau mencari pinjaman dengan bunga yang sangat tinggi. Hal ini yang bisa berakibat, banyaknya kredit bermasalah. Dengan gambaran seperti ini kemungkinan akan

${ }^{1}$ Frederic S. Mishkin dalam "Prudential Supervision Whal Works and What Doesn't: NBER Conference Report. Chicago, The University of Chicago Press. 2001. 
terjadi "Bank Runs", dimana pihak Bank akan menurunkan jumlah kreditnya dan memproteksi dirinya dengan mencadangkan lebih banyak likuiditas yang berakibat kontraksi dari sisi pemberian kredit. Selain itu juga akan menurunkan nilai agunan yang dimiliki oleh calon peminjam oleh pihak Bank.

(ii) "Moral Hazard", yaitu terjadinya sesudah transaksi dilakukan, dimana pemberi pinjaman berada pada posisi yang menerima resiko atas dimana usaha yang dilakukan peminjam "moral bazard" terjadi, karena peminjam memperoleh keuntungan untuk mengalihkan proyeknya pada proyek yang beresiko tinggi yang tidak diinginkan oleh pemberi pinjaman yang apabila berhasil dapat memberikan keuntungan yang besar dan apabila gagal akan ditanggung oleh pemberi pinjaman dalam bentuk tidak kembalinya kredit yang diberikan.

Kiranya, kerangka masalah asimetri inilah yang memegang peranan yang penting bagi institusi Perbankan dan Lembaga Keuangan dan Intermediasi lain yang khususnya memberikan kredit.

Dalam Pembangunan Nasional, Usaha Kecil Menengah dan Mikro sebagai bagian integral dunia usaha yang merupakan kegiatan ekonomi rakyat, mempunyai kedudukan, potensi, dan peran yang strategis untuk mewujudkan struktur perekonomian nasional yang makin seimbang berdasarkan demokrasi ekonomi.

Sehubungan dengan hal tersebut, Usaha Kecil Menengah dan Mikro ini perlu lebih diberdayakan dalam memanfaatkan peluang usaha dan menjawab tantangan perkembangan ekonomi di masa yang akan datang;

Peran UMKM dalam perekonomian sangat penting, baik dari jumlah pelaku, pembentukan nilai tambah, dalam penyerapan tenaga kerja, serta dalam memperkuat struktur ketahanan ekonomi.

Untuk itu, dalam perkembangannya, Bank dalam usaha memberikan pinjaman kepada UMKM, perlu mendapat dukungan dari suatu skim asuransi deposito, yang berfungsi sebagai penyedia jaring pengaman sosial (JPS), sehingga apabila terjadi kegagalan pada suatu Bank akan terlindungi aspek pengembalian kreditnya.

Namun di sisi peminjam juga perlu adanya suatu intermediasi, terutama peminjam yang tidak memiliki agunan, sehingga para pengusaha UMKM ini akan mendapatkan pinjaman dari Bank atau 
Lembaga Keuangan Bank lainnya.Salah satunya adalah dengan adanya Lembaga Penjamin Kredit.

Berdasarkan pertimbangan tersebut di atas, untuk memberikan dasar hukum bagi pemberdayaan Usaha Kecil perlu adanya Undangundang tentang Usaha Kecil Menengah dan Mikro tersebut.

\section{B. Landasan Teori}

\section{Pengertian UMKM dan Pengembangannya}

UMKM adalah Usaha Menengah, Kecil, dan Mikro.UMKM ini memiliki pagu kredit antara 50 sampai dengan 500 juta rupiah. Ketentuan yang diberikan para pemberi pinjaman kredit pada UMKM ini tidak berbeda dengan syarat dan ketentuan yang diberikan oleh Bnak Umum, namun dengan tingkat bunga yang lebih rendah, tentunya.

Dengan kata lain, masalah-masalah yang dihadapi para UMKM ini adalah susahnya para pengusaha UMKM dalam memperoleh pinjaman, karena tidak memiliki agunan, serta banyaknya jumlah pengusaha kecil, yang jumlahnya hampir mencapai jumlah 40 juta ini, yang tidak memiliki agunan untuk dijaminkan dalam proses peminjaman kredit di Bank.

Dalam Undang-Undangoleh Presiden Republik IndonesiaNomor: 9 Tahun 1995 (9/1995), Tanggal: 26 Desember 1995 (Jakarta), Pasal 1, Ayat 1 dan 2, dijelaskan mengenai apa itu Usaha Kecil, dan Menengah, antara lain adalah: ${ }^{2}$

1. Usaha Kecil adalah kegiatan ekonomi rakyat yang berskala kecil dan memenuhi kriteria kekayaan bersih atau hasil penjualan tahunan serta kepemilikan sebagaimana diatur dalam Undang-undang ini;

2. Usaha Menengah dan Usaha Besar adalah kegiatan ekonomi yang mempunyai kriteria kekayaan bersih atau hasil

2UNDANG-UNDANG (UU)Nomor: 9 TAHUN 1995 (9/1995) Tanggal: 26 DESEMBER 1995 (JAKARTA). Sumber: LN 74; TLN 3611. Tentang: USAHA KECIL 
penjualan tahunan lebih besar daripada kekayaan bersih dan hasil penjualan tahunan Usaha Kecil;

Adapun kriteria usaha kecil, adalah seperti yang diuraikan pada Bab IIIPasal 5 UU No. 9 Tahun 1995, yakni:

a. Memiliki kekayaan bersih paling banyak Rp.200.000.000,(dua ratus juta rupiah), tidak termasuk tanah dan bangunan tempat usaha; atau

b. Memiliki hasil penjualan tahunan paling banyak Rp. 1.000.000.000,- (satu milyar rupiah);

c. Milik Warga Negara Indonesia;

d. Berdiri sendiri, bukan merupakan anak perusahaan atau cabang perusahaan yangdimiliki, dikuasai, atau berafiliasi baik langsung maupun tidak langsung dengan Usaha Menengah atau Usaha Besar;

e. Berbentuk usaha orang perseorangan, badan usaha yang tidak berbadan hukum, atau badan usaha yang berbadan hukum, termasuk koperasi.

\section{Pengertian Kredit ${ }^{3}$ dan Jaminan Kredit}

Kredit berasal dari bahasa Yunani "Credere" yang berarti "Kepercayaan" atau "Trust".

John Stuart Mill mendefinisikan kredit sebagai "The Permission to Use Another's Capital."

Joseph French Johnson mendefinisikan kredit sebagai "The Power to Obtain Goods or Services by Giving a Promise to Payat a Specified Date in The Future".

Dengan kata lain, kredit adalah penyediaan uang atau tagihantagihan yang dapat disamakan dengan itu, berdasarkan persetujuan pinjam-meminjam antara Bank dengan lain pihak, dalam hal mana pihak peminjam berkewajiban melunasi utangnya setelah jangka waktu tertentu dengan jumlah bunga yang telah ditetapkan.

Kredit adalah suatu pemberian prestasi oleh suatu pihak kepada pihak lain, dan sebagai kontra prestasinya akan diterima bunga setelah jangka waktu tertentu.

${ }^{3}$ Amin Widjaja Tunggal, Ak. MBA. 1994. Dasar-Dasar Akuntansi Bank. Jakarta : Rineka Cipta. hlm.14. 
Bank berharap agar kredit yang diberikan pada debiturnya berjalan lancar sampai kredit dilunasi. UU Pokok Perbankan No. 14 Tahun 1967 Pasal 24 Ayat 1 menyebutkan bahwa: "Bank Umum tidak memberikan kredit tanpa jaminan kepada siapapun. Dengan demikian oleh Undang-Undang ditetapkan bahwa pemberian kredit harus dengan jaminan."

Kegunaan jaminan adalah apabila pada suatu saat seorang debitur melakukan wanprestasi (cidera janji) secara disengaja (sadar) atau tidak disengaja, untuk itu Bank berusaha agar debitur senantiasa memberikan hak dan kekuasaan kepada Bank untuk mendapatkan pelunasan utang dari barang-barang jaminan tadi apabila terjadi wanprestasi dengan jalan mengadakan pengikatan secara yuridis melalui suatu perjanjian kredit, baik dibawah tangan maupun secara notariil.

Resiko sewaktu-waktu seperti ini sudah disadari Bank, karena itu Bank perlu mengamankan jaminan bukan saja secara yuridis tetapi juga secara fisik. Perusahaan yang mengkhususkan diri dalam mengambil alih resiko atas fisik barang jaminan ialah perusabaan asuransi.

Dalam KUHD Pasal 246 disebutkan bahwa tujuan asuransi adalah untuk mencegah setidak-tidaknya mengurangi resiko kerugian yang mungkin timbul karena hilang, rusak, atau musnahnya barangbarang yang dipertanggungkan dari suatu kejadian yang tidak pasti. Selanjutnya dijelaskan pula, bahwa asuransi adalah suatu perjanjian dalam hal penanggung membebankan premi dan mengikat diri terhadap suatu tertanggung untuk membebaskannya dari kerugian.

Dengan demikian, asuransi merupakan hubungan hukum antara dua pihak yang saling terikat dalam suatu perjanjian yang mengakibatkan hak dan kewajiban antara "tertanggung" (insured/assured), yaitu pihak yang mempercayakan (mengasuransikan) miliknya terhadap suatu resiko yang mungkin terjadi, dan "penanggung" (insurer/under writer's), yaitu pihak yang menerima pertanggungan. Pihak ini lazim disebut "Perusahaan Asuransi".

4 Thomas Suyatno, M. M., dkk. 2005. Kelembagaan Perbankan. Edisi Ketiga. Jakarta: PT. Gramedia Pustaka Utama. hlm. 88. 


\section{Lembaga-Lembaga Penjamin Kredit}

Lembaga Penjamin Kredit (LPK) pertama kali berdiri tahun 1971. Setelah itu tahun 1972 didirikan pula Lembaga Jaminan Kredit Koperasi (JKK). Melalui ACSIC Indonesia dapat belajar bagaimana negara-negara maju itu mengembangkan strategi penjaminan kredit UKM yang efektif dan efisien.

Lembaga penjamin ini dibentuk berdasarkan peraturan perundang-undangan yang berlaku serta, lembaga lainnya yang ditetapkan sebagai lembaga penjamin

Lembaga Penjamin Kredit bertujuan meningkatkan utilitas potensi serta kapasitas dan inovasi UMKM yang tidak cukup agunan dalam pengajuan kredit ke Bank atau sumber lainnya.

Lembaga Penjamin Kredit mempunyai kewajiban memikul kerugian yang disebabkan oleh kesalahan salah satu pihak, yang disebut sebagai resiko. Adapun kewajiban-kewajiban tersebut dapat dilihat seperti pada Pasal 43 Kompilasi Hukum Syariah, sebagai berikut: $^{5}$

1) Kewajiban menanggung kerugian yang disebabkan oleh kejadian diluar kesalahan salah satu pihak dalam akad, dalam perjanjian sepihak dipikul oleh peminjam;

2) Kewajiban menanggung kerugian yang disebabkan oleh kejadian diluar kesalahan salah satu pihak dalam perjanjian timbal balik, dipikul oleh yang meminjamkan.

\subsection{PT. Askrindo}

Pemerintah Indonesia melalui Departemen Keuangan dan Bank Indonesia mendirikan PT. Asuransi Kredit Indonesia (Askrindo) sebagai lembaga penjamin kredit pertama di Indonesia.

PT. Askrindo (Asuransi Kredit Indonesia) bergerak di bidang penjaminan kredit untuk KUKM selama 34 tahun lebih. Adapun bentuk skim UMK yang telah dilakukan Askrindo adalah:

(i) Penjaminan kredit secara otomatis UMK mengajukan krdit kepada Bank. Bank merealisasikan kredit ke UMK.

${ }^{5}$ Mahkamah Agung Republik Indonesia. 2008. Kompilasi Hukum Ekonomi Syariah. hlm. 17. 
Selanjutnya Bank mengajukan penjaminan kredit kepada Askrindo menjamin kredit yang diberikan Bank ke UMK.

(ii) Penjaminan kredit secara kasus per kasus UMK mengajukan kredit pada Bank-Bank. Bank mengajukan kepada Askrindo. Askrindo menjamin kredit yang diberikan kepada UMK. Bank merealisasikan kredit kepada UMK.

(iii) Penjaminan kredit Massal UMK mengajukan kredit massal kepada Bank. Bank mengajukan pinjaman kepada Askrindo dan Bank merealisasikan kredit massal kepada UMK.

(iv) Penjaminan kredit secara langsung UMK mengajukan penjaminan kredit kepada Askrindo berdasarkan surat penjaminan kredit. UMK mengajukan kepada Bank yang dijamin Askrindo dan Bank merealisasikan kredit kepada UMK.

\subsection{Perum Sarana Pengembangan Usaha (SPU).}

Konsep penjaminan Perum SPU pada dasarnya berfungsi melengkapi kebutuhan dua pihak yaitu Koperasi dan UKM yang belum memiliki kolateral yang cukup sesuai dengan dipersyaratkan kreditor akan proteksi pengembalian kreditnya bilamana terdapat wanprestasi karena gagal usaha.

Dasar hukum keberadaan Perum SPU adalah PP No. 95 Tahun 2000 tentang Perum Sarana Pengembagan Usaha. Berdasarkan No. 95 Tahun 2000, fungsi Perum SPU adalah menyelenggarakan usaha penjaminan kredit yaitu melakukan kegiatan yang dilaksanakan dalam bentuk pemberian penjaminan untuk KUKM guna memperoleh kredit dari kreditur baik perbankan maupun badan usaha pemberi kredit lainnya.

Berdasarkan hal itu kedudukan Perum SPU adalah sebagai penjamin, KUKM sebagai pihak terjamin dan sebagai pihak penerima jaminan. Manfaat utama dari penjaminan adalah penutup kekurangan atau substitusi kolateral bagi pihak-pihak terjaminan. Likuiditas pada saat pasca kredit macet bagi pihak penerima jaminan.

Sektor usaha yang dijamin terdiri dari kredit modal kerja dan kredit investasi untuk sektor pertanian, perkebunan, perikanan, 
perkebunan, perikanan, peternakan, pertambangan, industri, dan perdagangan.

\section{Konsep Kemaslahatan}

Menurut As-Syatibi, Maslahah adalah sifat atau kekuatan barang atau jasa yang mempengaruhi atau memenuhi unsur-unsur dasar dan tujuan-tujuan hidup manusia di dunia ini.

As-Syatibi menggambarkan lima fundamen kehidupan di dunia ini, yaitu:

(1) Jiwa;

(2) Kekayaan;

(3) Kepercayaan;

(4) Akal; dan

(5) Keturunan.

Setiap barang atau jasa yang memiliki kekuatan untuk mempromosikan kelima elemen tersebut, maka dikatakan memiliki maslahah untuk umat manusia, yang otomatis disebut kebutuhan.

Maslahah individu akan selalu konsisten dengan maslabah sosial. Konsep maslahah mendasari seluruh aktivitas ekonomi dalam masyarakat; konsumsi, produksi, dan distribusi.

\section{Pembahasan}

\section{Undang-Undang (UU)Nomor: 9 Tahun 1995 (9/1995)} Tanggal: 26 Desember 1995 (Jakarta). Sumber: LN 74; TLN 3611.Tentang: Usaha Kecil

Dalam UU No. Pasal 22 Tahun 1995, Pemerintah berusaha untuk meningkatkan akses Usaha Kecil terhadap pembiayaan melalui cara-cara:

a. Meningkatkan kemampuan dalam pemupukan modal sendiri;

b. Meningkatkan kemampuan menyusun studi kelayakan;

c. Meningkatkan kemampuan manajemen keuangan;

d. Menumbuhkan dan mengembangkan lembaga penjamin.

Usaha-usaha lainnya dari Pemerintah bagi pembiayaan UMKM ini adalah: 
(1) Pembiayaan bagi Usaha Kecil dapat dijamin oleh lembaga penjamin yang dimiliki Pemerintah dan/atau swasta.

(2) Lembaga penjamin sebagaimana dimaksud dalam ayat (1) menjamin pembiayaan Usaha Kecil dalam bentuk:

a. Penjaminan pembiayaan kredit perbankan;

b. Penjaminan pembiayaan atas bagi hasil;

c. Penjaminan pembiayaan lainnya.

Pembiayaan dan penjaminan sebagaimana dimaksud di atas adalah menyangkut alokasi, tata cara, prioritas, serta jangka waktu pembiayaan dan penjaminan dilaksanakan dengan memperhatikan klasifikasi dan tingkat perkembangan Usaha Kecil.

Penyertaan modal negara merupakan salah satu strategi yang tepat bagi Indonesia dalam memperkuat LPK. Permodalan yang kuat bagi sebuah LPK mutlak diperlukan mengingat modal merupakan indikator utama dalam menanggung resiko.

Dengan adanya penyertaan modal tersebut menyebabkan LPK dapat memperbesar kapasitas penjaminan sekaligus terjaminnya sustainability karena didukung Pemerintah.

\section{a. Iklim Usaha}

Iklim usaha adalah kondisi yang diupayakan Pemerintah berupa penetapan berbagai peraturan perundang-undangan dan kebijaksanaan di berbagai aspek kehidupan ekonomi agar Usaha Kecil memperoleh kepastian kesempatan yang sama dan dukungan berusaha yang seluas-luasnya sehingga berkembang menjadi usaha yang tangguh dan mandiri;

Pemerintah menumbuhkan iklim usaha bagi Usaha Kecil melalui penetapan peraturan perundang-undangan dan kebijaksanaan meliputi aspek:

1) Pendanaan;

2) Persaingan;

3) Prasarana;

4) Informasi;

5) Kemitraan;

6) Perizinan usaha; dan

7) Perlindungan. 
Pemerintah menumbuhkan iklim usaha dalam aspek pendanaan untuk:

1) Memperluas sumber pendanaan;

2) Meningkatkan akses terhadap sumber pendanaan;

3) Memberikan kemudahan dalam pendanaan.

Pemerintah menumbuhkan iklim usaha dalam aspek persaingan untuk:

1) Meningkatkan kerja sama sesama Usaha Kecil dalam bentuk koperasi, asosiasi, dan himpunan kelompok usaha untuk memperkuat posisi tawar Usaha Kecil;

2) Mencegah pembentukan struktur pasar yang dapat melahirkan persaingan yang tidak wajar dalam bentuk monopoli, oligopoli, dan monopsoni yang merugikan Usaha Kecil;

3) Mencegah terjadinya penguasaan pasar dan pemusatan usaha oleh orang-perseorangan atau kelompok tertentu yang merugikan Usaha Kecil.

Pemerintah menumbuhkan iklim usaha dalam aspek prasarana untuk:

1) Mengadakan prasarana umum yang dapat mendorong dan mengembangkan pertumbuhan Usaha Kecil;

2) Memberikan keringanan tarif prasarana tertentu bagi Usaha Kecil.

Pemerintah menumbuhkan iklim usaha dalam aspek informasi untuk:

1) Membentuk dan memanfaatkan Bank Data dan jaringan informasi bisnis;

2) Mengadakan dan menyebarkan informasi mengenai pasar, teknologi, desain, dan mutu.

Pemerintah menumbuhkan iklim usaha dalam aspek kemitraan untuk:

1) Mewujudkan kemitraan;

2) Mencegah terjadinya hal-hal yang merugikan Usaha Kecil dalam pelaksanaan transaksi usaha dengan Usaha Menengah dan Usaha Besar.

Pemerintah menumbuhkan iklim usaha dalam aspek perizinan usaha untuk: 
1) Menyederhanakan tata cara dan jenis perizinan dengan mengupayakan terwujudnya sistem pelayanan satu atap;

2) Memberikan kemudahan persyaratan untuk memperoleh perizinan.

Pemerintah menumbuhkan iklim usaha dalam aspek perlindungan untuk:

1) Menentukan peruntukan tempat usaha yang meliputi pemberian lokasi di pasar, ruang pertokoan, lokasi sentra industri, lokasi pertanian rakyat, lokasi pertambangan rakyat, dan lokasi yang wajar bagi pedagang kaki lima, serta lokasi lainnya;

2) Mencadangkan bidang dan jenis kegiatan usaha yang memiliki kekhususan proses, bersifat padat karya, serta mempunyai nilai seni budaya yang bersifat khusus dan turun temurun;

3) Mengutamakan penggunaan produk yang dihasilkan Usaha Kecil melalui pengadaan secara langsung dari Usaha Kecil;

4) Mengatur pengadaan barang atau jasa dan pemborongan kerja Pemerintah;

5) Memberikan bantuan konsultasi hukum dan pembelaan.

\section{b. Pemberdayaan dan Pengembangan}

Pemberdayaan adalah upaya yang dilakukan oleh Pemerintah, dunia usaha, dan masyarakat dalam bentuk penumbuhan iklim usaha, pembinaan dan pengembangan sehingga Usaha Kecil mampu menumbuhkan dan memperkuat dirinya menjadi usaha yang tangguh dan mandiri;

Pemberdayaan Usaha Kecil diselenggarakan atas asas kekeluargaan.Pemberdayaan Usaha Kecil bertujuan:

1) Menumbuhkan dan meningkatkan kemampuan Usaha Kecil menjadi usaha yangtangguh dan mandiri serta dapat berkembang menjadi Usaha Menengah;

2) Meningkatkan peranan Usaha Kecil dalam pembentukan produk nasional, perluasan kesempatan kerja dan berusaha, meningkatkan ekspor, serta peningkatan dan pemerataan pendapatan untuk mewujudkan dirinya sebagai tulang 
punggung serta memperkukuh struktur perekonomian nasional.

Kegiatan-kegiatan dalam rangka pengembangan UMKM yang banyak dibicarakan adalah:

1) Kegiatan yang mengarah pada penguatan modal usaha UMKM;

2) Peningkatan kemampuan pengelolaan UMKM;

3) Peningkatan daya saing produk;

4) Pemasaran;

5) Pengembangan kemitraan dengan pelaku usaha lainnya;

6) Lembaga Keuangan Mikro yang mampu menyalurkan kredit dengan syarat-syarat yang dapat dipenuhi para UMKM;

7) Sesuai waktu;

8) Sesuai besaran kebutuhan UMKM untuk usaha.

\section{c. Kemitraan}

Kemitraan adalah kerja sama usaha antara Usaha Kecil dengan Usaha Menengah atau dengan Usaha Besar disertai pembinaan dan pengembangan oleh Usaha Menengah atau Usaha Besar dengan memperhatikan prinsip saling memerlukan, saling memperkuat, dan saling menguntungkan.Di bawah ini pasal-pasal tentang usaha-usaha yang dilakukan oleh Pemerintah dalam membina para pengusaha UMKM, yaitu:

1) Usaha Menengah dan Usaha Besar melaksanakan hubungan kemitraan dengan Usaha Kecil, baik yang memiliki maupun yang tidak memiliki keterkaitan usaha.

2) Pelaksanaan hubungan kemitraan sebagaimana dimaksud dalam ayat (1) diupayakan ke arah terwujudnya keterkaitan usaha.

3) Kemitraan dilaksanakan dengan disertai pembinaan dan pengembangan dalam salah satu atau lebih bidang produksi dan pengolahan, pemasaran, permodalan, sumber daya manusia, dan teknologi.

4) Dalam melakukan hubungan kemitraan kedua belah pihak mempunyai kedudukan hukum yang setara.

Kemitraan dilaksanakan dengan pola: 
1) Inti-plasma

2) Subkontrak;

3) Dagang umum;

4) Waralaba;

5) Keagenan; dan

6) Bentuk-bentuk lain.

Hubungan kemitraan dituangkan dalam bentuk perjanjian tertulis yang sekurang-kurangnya mengatur bentuk dan lingkup kegiatan usaha kemitraan, hak dan kewajiban masing-masing pihak, bentuk pembinaan dan pengembangan, serta jangka waktu dan penyelesaian perselisihan.

Pelaksanaan hubungan kemitraan yang berhasil antara Usaha Menengah atauUsaha Besar dengan Usaha Kecil ditindaklanjuti dengan kesempatan pemilikan saham Usaha Menengah atau Usaha Besar oleh Usaha Kecil mitra usahanya dengan harga yang wajar.

Dalam pelaksanaan hubungan kemitraan sebagaimana dimaksud dalam Pasal 26, Usaha Menengah atau Usaha Besar dilarang memiliki dan/atau menguasai Usaha Kecil mitra usahanya.

Ketentuan mengenai tata cara pelaksanaan kemitraan diatur lebih lanjut dengan Peraturan Pemerintah.

\section{d. Pembinaan dan Pengembangan}

Pembinaan dan pengembangan adalah upaya yang dilakukan oleh Pemerintah dunia usaha dan masyarakat melalui pemberian bimbingan dan bantuan perkuatan untuk menumbuhkan dan meningkatkan kemampuan Usaha Kecil agar menjadi usaha yang tangguh dan mandiri;

Pembiayaan adalah penyediaan dana oleh Pemerintah, dunia usaha, dan masyarakat melalui lembaga keuangan bank, lembaga keuangan bukan bank, atau melalui lembaga lain dalam rangka memperkuat permodalan Usaha Kecil;

Penjaminan adalah pemberian jaminan pinjaman Usaha Kecil oleh lembaga penjamin sebagai dukungan untuk memperbesar kesempatan memperoleh pembiayaan dalam rangka memperkuat permodalannya;

Pemerintah, dunia usaha, dan masyarakat melakukan pembinaan dan pengembangan Usaha Kecil dalam bidang: 
1) Produksi dan pengolahan;

2) Pemasaran;

3) Sumber daya manusia; dan

4) Teknologi.

Pemerintah, dunia usaha, dan masyarakat melakukan pembinaan danpengembangandalam bidang produksi dan pengolahandengan:

1) Meningkatkan kemampuan manajemen serta teknik produksi dan pengolahan;

2) Meningkatkan kemampuan rancang bangun dan perekayasaan;

3) Memberikan kemudahan dalam pengadaan sarana dan prasarana produksi dan pengolahan, bahan baku, bahan penolong, dan kemasan.

Pemerintah, dunia usaha, dan masyarakat melakukan pembinaan danpengembangan dalam bidang pemasaran, baik di dalam maupun di luar negeri, dengan:

1) Melaksanakan penelitian dan pengkajian pemasaran;

2) Meningkatkan kemampuan manajemen dan teknik pemasaran;

3) Menyediakan sarana serta dukungan promosi dan uji coba pasar;

4) Mengembangkan lembaga pemasaran dan jaringan distribusi;

5) Memasarkan produk Usaha Kecil.

Pemerintah, dunia usaha, dan masyarakat melakukan Pembinaan dan pengembangandalam bidang sumber daya manusia dengan:

1) Memasyarakatkan dan membudayakan kewirausahaan;

2) Meningkatkan keterampilan teknis dan manajerial;

3) Membentuk dan mengembangkan lembaga pendidikan, pelatihan, dan konsultasi Usaha Kecil;

4) Menyediakan tenaga penyuluh dan konsultan Usaha Kecil.

Pemerintah, dunia usaha, dan masyarakat melakukan pembinaan dan pengembangan dalam bidang teknologi dengan:

1) Meningkatkan kemampuan di bidang teknologi produksi dan pengendalian mutu; 
2) Meningkatkan kemampuan di bidang penelitian untuk mengembangkan desain dan teknologi baru;

3) Memberi insentif kepada Usaha Kecil yang menerapkan teknologi baru dan melestarikan lingkungan hidup;

4) Meningkatkan kerjasama dan alih teknologi;

5) Meningkatkan kemampuan memenuhi standardisasi tekno$\log$;

6) Menumbuhkan dan mengembangkan lembaga penelitian dan pengembangan di bidang desain dan teknologi bagi Usaha Kecil.

Pembinaan ini mencakup:

1) Pembinaan dan pengembangan sebagaimana dimaksud dalam Pasal 14, yang menyangkut tata cara, bobot, intensitas, prioritas, dan jangka waktu pembinaan dan pengembangannya, dilaksanakan dengan memperhatikan klasifikasi dan tingkat perkembangan Usaha Kecil yang bersangkutan.

2) Ketentuan mengenai tata cara, bobot, intensitas, prioritas, dan jangka waktu pembinaan dan pengembangan sebagaimana dimaksud dalam ayat (1) diatur lebih lanjut dengan Peraturan Pemerintah.

Tindak lanjut dari pembinaan ini adalah:

1) Usaha Kecil yang telah dibina dan berkembang menjadi Usaha Menengah masih dapat diberikan pembinaan dan pengembangan dalam jangka waktu paling lama tiga tahun.

2) Pemerintah menetapkan bidang pembinaan dan pengembangan yang masih perlu diberikan kepada Usaha Menengah sebagaimana dimaksud dalam ayat (1).

3) Usaha Kecil yang telah dibina dan berkembang menjadi Usaha Menengah tetap dapat menempati lokasi usaha dan melakukan kegiatan usaha yang dicadangkan.

\section{Koordinasi dan Pengendalian}

a. Presiden menunjuk Menteri yang membidangi Usaha Kecil yang bertanggung jawab atas, serta mengkoordinasikan dan mengendalikan pemberdayaan Usaha Kecil. 
b. Untuk memantapkan koordinasi dan pengendalian, Presiden dapat membentuk lembaga koordinasi dan pengendalian pemberdayaan Usaha Kecil yang dipimpin oleh Menteri sebagaimana dimaksud dalam ayat (1) dengan anggota-anggotanya terdiri dari unsur Pemerintah, pengusaha, tenaga ahli, tokoh dan lembaga swadaya masyarakat.

c. Koordinasi dan pengendalian sebagaimana dimaksud dalam ayat (1), meliputi penyusunan kebijaksanaan dan program pelaksanaan, pemantauan, evaluasi serta pengendalian umum terhadap pelaksanaan pemberdayaan Usaha Kecil.

\section{Sanksi Administratif}

Dalam UU No. 9 Tahun 1995 Pasal 36, disebutkan sanksisanksi yang akan dijatuhkan oleh Pemerintah kepada para pelaku kejahatahan tindak pidana usaha, yaitu:

(1) Usaha Menengah atau Usaha Besar yang dengan sengaja melanggar ketentuan Pasal 31, yaitu Pasal 316 dikenakan sanksi administratif berupa pencabutan izin usaha dan atau denda paling banyak Rp. 5.000.000.000,- (lima milyar rupiah) oleh instansi yang berwenang.

(2) Jika tindak pidana sebagaimana dimaksud dalam Pasal 34 dilakukan oleh atau atas nama badan usaha, dapat dikenakan sanksi administratif berupa pencabutan sementara atau pencabutan tetap izin usaha oleh instansi berwenang.

\section{Kesimpulan}

Permasalahan yang terjadi di dunia perekonomian, khususnya pendanaan, tidak terlepas dari unsur-unsur individu pelaku ekonomi, serta peran Pemerintah selaku pusat pelaksana pembuat kebijakan.

6 UU No. 9 Tahun 1995 Pasal 31 dinyatakan: "Dalam pelaksanaan hubungan kemitraan sebagaimana dimaksud dalam Pasal 26, Usaha Menengah atau Usaha Besar dilarang memiliki dan/atau menguasai Usaha Kecil mitra usahanya." 
160 | Adliya, Vol. 8 No. 1, Edisi: Januari-Juni 2014

Berikut ini skema tentang permasalahan yang sering terjadi, serta peran Pemerintah terhadap para pelaku ekonominya:

Sanksi Administratif

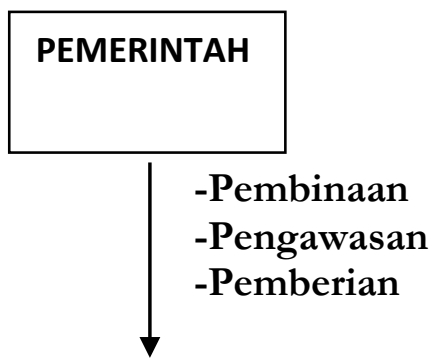

(-) "Adverse Selection"

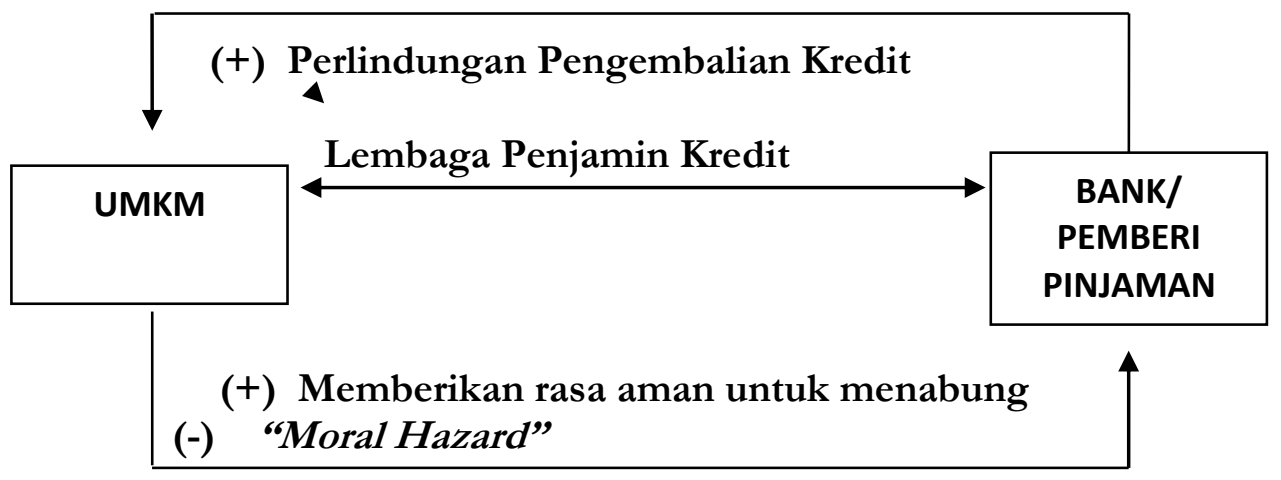

Permasalahan UMKM adalah rendahnya akses terhadap sumber permodalan karena terbatasnya jaminan atau agunan, terbatasnya kualitas produk, serta terbatasnya kemampuan memasarkan produk yang dihasilkan.

Prinsip kehati-hatian dilakukan oleh pihak Bank terhadap calon peminjam karena adanya permasalahan asimetri("Adverse Selection" dan "Moral Hazard") antara pihak Bank dengan pihak peminjam.

Dalam perkembangannya, Bank dalam usaha memberikan pinjaman kepada UMKM, perlu mendapat dukungan dari suatu skim asuransi deposito, yang berfungsi sebagai penyedia jaring pengaman sosial (JPS), sehingga apabila terjadi kegagalan pada suatu Bank akan terlindungi aspek pengembalian kreditnya.Di sisi peminjam juga perlu adanya suatu intermediasi bagi para peminjam yang tidak mempunyai agunan, yang memungkinkan para pengusaha UMKM 
ini akan mendapatkan pinjaman dari Bank atau Lembaga Keuangan lainnya. Salah satunya adalah dengan adanya Lembaga Penjamin Kredit.

Kehadiran Lembaga Penjamin Kredit diharapkan mampu menjadi pelengkap bagi UMKM untuk mendapat modal usaha dengan mudah. Namun demikian ada hal-hal positif dan negatif dengan adanya Lembaga Penjamin Kredit ini, antara lain:

1. Hal-hal positif:

a) Bagi Bank : Memberikan perlindungan bagi Bank agar nilai kreditnya tidak hilang

b) Bagi Nasabah : Memberikan rasa aman pada para nasabah, sehingga memacu mereka untuk menabung, dan mengajukan kredit usaha.

2. Hal-hal negatif:

a) Bagi Bank :Membuat para Bank malas meningkatkan keragaan Banknya.

b) Bagi Nasabah :Timbulnya "Moral Hazard" dari para debitur yang malas dan licik.

Pembinaan dan pengembangan adalah upaya yang dilakukan oleh Pemerintah melalui pemberian bimbingan dan bantuan perkuatan, untuk menumbuhkan dan meningkatkan kemampuan Usaha Kecil agar menjadi usaha yang tangguh dan mandiri;

Selain itu,pengawasan, pengendalian, serta sanksi administratif, juga dilakukan agar tercipta perekonomian yang stabil dan berkembang dengan baik, serta untuk mengantisipasi munculnya kembali permasalahan asimetri dalam dunia perekonomian ini.

Konsep kemaslahatan berpengaruh penting terhadap sejauh mana pelaku ekonomi memahami arti dari perilaku yang mereka ambil, serta efek yang ditimbulkannya terhadap lingkungan sekitarnya. Karena apabila individu pelaku ekonomi telah memahami dan menjalankan maslahah itu, maka roda perekonomian akan berjalan seimbang dan tidak timpang. Karena konsep maslahah individu akan selalu konsisten dengan maslahah sosial. Denganmemahami konsep maslahah maka "Adverse Selection" dan "Moral Hazard", Insya Allah tidak akan terjadi. 
Dari semua hal di atas, penulis berharap banyak hal-hal positiflah yang akan sering kita temukan di lapangan dengan adanya keberadaan, fungsi, serta tugas dari Lembaga Penjamin Kredit ini. Sehingga kelancaran antara fungsi Bank sebagai pemberi pinjaman, dan pihak peminjam, akan terjalin kerjasama yang baik dan utuh. Dengan demikian laju perekonomian, khususnya, bagi pengusaha penyandang dana kecil yang tidak memiliki agunan, akan berjalan baik, bahkan lebih baik dan berhasil.

\section{DAFTAR PUSTAKA}

http://www.antara.co.id/arc/2007/11/6/lembaga-penjamin-kreditperkuat-ukm/

http://www.antara.co.id/arc/2007/9/3/pemerintah-ajukan-empatskenario-penggunaan-dana-pmn/

http://www.hamline.edu/apakabar/basisdata/1995/05/19/0006.ht $\mathrm{m} /$

http://www.jabar.go.id/jabar/public/33437/artikel_detail.htm?id=8 2924

Mahkamah Agung Republik Indonesia. 2008.Kompilasi Hukum Ekonomi Syariah.

Majalah KUKM, Edisi Oktober 2007 terbitan Dinas KUKM \& Koperasi Prov. Jabar.

Milshkin, Frederic S. 2001. 'Prudential Supervision Whal Works and

What Doesn't:. NBER Conference Report. Chicago, The

University of Chicago Press.

Suyatno, Thomas, dkk. 2005. Kelembagaan Perbankan. Edisi Ketiga. Jakarta: PT. Gramedi Pustaka Utama.

Undang-Undang (UU)Nomor: 9 Tahun 1995 (9/1995) Tanggal: 26 Desember 1995 (Jakarta). Sumber: LN 74; TLN 3611.Tentang: Usaha Kecil

Widjaja Tunggal, Amin Widjaja. 1994. Dasar-Dasar Akuntansi Bank. Jakarta: Rineka Cipta. 